\title{
Isolation and characterisation of a novel Bohle-like virus from two frog species in the Darwin rural area, Australia
}

\author{
R. P. Weir ${ }^{1, *}$, N. J. G. Moody ${ }^{2}$, A. D. Hyatt ${ }^{2}$, S. Crameri ${ }^{2}$, R. Voysey $^{2}$, J. Pallister ${ }^{2}$, \\ I. V. Jerrett ${ }^{1}$ \\ ${ }^{1}$ Department of Resources, PO Box 3000, Darwin, Northern Territory 0800, Australia \\ ${ }^{2}$ Australian Animal Health Laboratory, Private Bag 24, Geelong, Victoria 3220, Australia
}

\begin{abstract}
Twelve captive magnificent tree frogs Litoria splendida and 2 green tree frogs $L$. caerulea on a property in the Darwin rural area (Northern Territory, Australia) either died or were euthanased after becoming lethargic or developing skin lesions. Samples from both species of frog were submitted for histopathology and virus isolation. An irido-like virus was cultured from tissue samples taken from both species and was characterised using electron microscopy, restriction enzyme digests and nucleic acid amplification and sequencing. The isolates were determined to belong to the genus Ranavirus, were indistinguishable from each other and shared a $98.62 \%$ nucleotide similarity and a $97.32 \%$ deduced amino acid homology with the Bohle iridovirus over a $1161 \mathrm{bp}$ region of the major capsid gene. This is the first isolation of a ranavirus from amphibians in the Northern Territory and the first report of natural infection in these 2 species of native frog. The virus is tentatively named Mahaffey Road virus (MHRV).
\end{abstract}

KEY WORDS: Ranavirus · Bohle virus · Iridovirus · Amphibians · Mahaffey Road virus · Litoria spp.

\section{INTRODUCTION}

The family Iridoviridae comprises 5 generaIridovirus, Chloriridovirus, Ranavirus, Lymphocystivirus and Megalocytivirus. Virions are enveloped, 120 to $200 \mathrm{~nm}$ in diameter and display icosahedral symmetry with an electron-dense core, containing a single linear, circularly permuted and terminally redundant double-stranded DNA molecule of between 140 and $303 \mathrm{kbp}$. Virions are stable in water at $4{ }^{\circ} \mathrm{C}$ for extended periods and are able to resist desiccation at $42^{\circ} \mathrm{C}$ for up to $6 \mathrm{wk}$ (Fauquet et al. 2005).

Ranaviruses have been isolated from amphibians, fish and reptiles primarily located in North and South America, Europe and SE Asia (Zupanovic et al. 1998, Hyatt et al. 2000, Fauquet et al. 2005, Fox et al. 2006, Densmore \& Green 2007, Chinchar et al. 2009). Virus isolates show serological and genetic relatedness within the genus Ranavirus but are serologically and genetically distinct from members of other genera within the Iridoviridae (Fauquet et al. 2005). In Australia, 2 ranaviruses have been identified: epizootic haematopoietic necrosis virus (EHNV) from redfin perch Perca fluviatilis (Langdon et al. 1986) and rainbow trout Oncorhynchus mykiss (formerly Salmo gairdneri) (Langdon et al. 1988) and Bohle iridovirus (BIV) from metamorphs of the ornate burrowing frog Limnodynastes ornatus (Gray) (Speare \& Smith 1992, Marsh et al. 2002).

Studies conducted by Langdon et al. (1988), Moody \& Owens (1994) and Cullen \& Owens (2002) demonstrated the lethal potential of ranaviruses to native and introduced Australian amphibians and finfish using laboratory-based challenge trials. The ability of ranaviruses to infect a wide range of host species, including finfish, suggested a major risk 
associated with national and international trade in wildlife and translocation of pathogens (Hyatt et al. 2002).

In March 2008, mortalities occurred in a group of magnificent tree frogs Litoria splendida and 2 green tree frogs L. caerulea on a property in the Darwin rural area (Northern Territory, Australia). The facility where the mortalities occurred bred native frogs for the commercial pet trade. The affected group comprised brood stock collected from the Bullo River area of the Northern Territory and their progeny. Eight of a group of 12 magnificent tree frogs died over a $10 \mathrm{~d}$ period, and the remaining 4 frogs were euthanased after appearing lethargic or developing skin lesions. One week later, 2 of 13 green tree frogs in an adjacent pen were found dead. A virus was isolated from the affected animals and determined by a variety of techniques to be a ranavirus closely related to BIV. This is the first isolation of a ranavirus from a natural infection in L. splendida and L. caerulea, and the first in Australia from affected adult frogs.

\section{MATERIALS AND METHODS}

\section{Histopathology}

A wide range of tissues taken from the cadavers of both Litoria splendida and L. caerulea at necropsy were used for histopathological examination. Tissues were fixed in 10\% neutral buffered formalin and dehydrated through graded alcohols and xylol before being embedded in paraffin wax. Sections of $4 \mu \mathrm{m}$ thickness were cut from each sample and stained with haematoxylin and eosin. Spleen, liver, lip, kidney, heart, lung, stomach and intestine were studied.

\section{Virus isolation}

Upon post-mortem examination, samples of liver, spleen and lip lesions from both frog species were processed for virus isolation. Samples were homogenised individually in brain heart infusion broth containing penicillin $\mathrm{G}\left(6 \mathrm{mg} \mathrm{ml}^{-1}\right)$, streptomycin sulphate (20 mg ml-1) and amphotericin B (2.5 mg ml-1). Each homogenate was then transferred to a $10 \mathrm{ml}$ centrifuge tube containing $5 \mathrm{ml}$ of brain heart infusion broth and antibiotics and held overnight at $4^{\circ} \mathrm{C}$ prior to clarification by centrifugation $\left(2000 \times g\right.$ for $15 \mathrm{~min}$ at $\left.4^{\circ} \mathrm{C}\right)$.

The following day, confluent monolayers of bluegill fry (BF-2, ATCC-CCL-91) cells, cultured in Eagle minimum essential medium containing $5 \%$ foetal bovine serum and antibiotics in $25 \mathrm{~cm}^{2}$ cell culture flasks, were inoculated (each with $200 \mu \mathrm{l}$ ) and examined daily for the presence of cytopathic effect (CPE). Any grossly contaminated homogenates were processed last after filtration through a $0.22 \mu \mathrm{m}$ sterile membrane filter (Sartorius or Millipore). Samples were also inoculated onto BSR (Sato et al. 1977), African green monkey (VERO; ATCC-CCL-81) madin darby bovine kidney (MDBK; ATCC-CCL-22), porcine kidney (PSEK), Aedes albopictus (C6/36; ATCCCRL-1660) and primary crocodile cell cultures. To amplify virus for molecular analyses, $24 \mathrm{~h}$ old BF-2 cell cultures were inoculated with virus isolates at dilutions of $1 / 20,1 / 200$ and $1 / 2000$, incubated at $25^{\circ} \mathrm{C}$ and monitored daily for the appearance of CPE.

\section{Electron microscopy}

Clarified homogenates were inoculated onto BF2 cells as described above. When CPE was apparent, supernatant was adsorbed onto formvar-filmed, carbon-coated copper grids and stained with $2 \%$ (w/v) phosphotungstic acid ( $\mathrm{pH}$ 6.8) for 1 min. Scraped cells were pelleted by low speed centrifugation (2000 $\times g$ for $3 \mathrm{~min})$, fixed in $2.5 \%(\mathrm{v} / \mathrm{v})$ glutaraldehyde in $0.1 \mathrm{M}$ cacodylate buffer ( $\mathrm{pH} 7.2,300 \mathrm{mOsm} \mathrm{l}^{-1}$ ) for $40 \mathrm{~min}$, rinsed in $0.1 \mathrm{M}$ cacodylate buffer $(3 \times 20 \mathrm{~min})$, post fixed with $1 \%(\mathrm{w} / \mathrm{v})$ osmium tetroxide $0.1 \mathrm{M}$ cacodylate buffer $(1 \mathrm{~h})$ and rinsed with milli-Q water $(3 \times 5 \mathrm{~min})$. The cells were dehydrated through graded ethanol (70 to $100 \%$ ) and infiltrated and embedded in Spurr's epoxy resin. Ultrathin sections were double-stained in uranyl acetate and lead citrate and examined in a Philips CM120 transmission electron microscope at $120 \mathrm{kV}$.

\section{Laser dissection}

Haematoxylin and eosin stained sections of identified lesions (see 'Histopathology') from Litoria caerulea were examined with a Leica laser dissection microscope (LMD6500). Lesions were excised, collected into sterile Eppendorf tubes and examined via conventional PCR, sequencing and phylogenetic analysis for the presence of ranavirus.

\section{Restriction enzyme digests}

To compare nucleic acid profiles, DNA from the isolate (472 ng), BIV (1047 ng) and EHNV (240 ng) 
were digested at $37^{\circ} \mathrm{C}$ for $2 \mathrm{~h}$ in a $30 \mu$ single digest reaction containing 40 units of the restriction enzymes Xba I (New England Biolabs), Kpn I (Promega) and HindIII (New England Biolabs). Digests were analysed on a $0.8 \%$ agarose gel and visualised using SYBR Safe DNA gel stain (Invitrogen) and a bluelight transilluminator.

\section{Conventional PCR, sequencing and phylogenetic analysis}

Infected cell cultures were clarified by centrifugation at $10000 \times g$ for $10 \mathrm{~min}$, and nucleic acid was extracted from $140 \mu \mathrm{l}$ supernatant using a commercial spin column kit according to the manufacturer's instructions (QIAamp Viral RNA Kit, Qiagen). In addition to the test sample, nucleic acid was also extracted from $140 \mu \mathrm{l}$ aliquots of clarified tissue culture supernatant from uninfected cell cultures, and cell cultures containing BIV, EHNV (EHNVrt: rainbow trout isolate; EHNVrp: redfin perch isolate) and red seabream iridovirus (RSIV).

For diagnostic purposes, the $151 \mathrm{~F} / 152 \mathrm{R}$ primer set (based on 2 primer sets recommended by the World Organisation for Animal Health for the detection of EHNV (Manual of Diagnostic Tests for Aquatic Animals 2009, www.oie.int/fileadmin/Home/eng/Health_ standards/aahm/2010/2.3.01_EHN.pdf) was used to produce a $321 \mathrm{bp}$ amplicon and the 153F/154R primer set to produce a separate $625 \mathrm{bp}$ amplicon of the ranavirus major capsid protein open reading frame were used. The regions amplified correspond to bases 191 to 511 and 767 to 1391 of the EHNV capsid gene sequence (AY187045). For phylogenetic analysis, the $151 \mathrm{~F} / 154 \mathrm{R}$ primer combination was used to produce a $1161 \mathrm{bp}$ amplicon, corresponding to bases 191 to 1391 of the EHNV capsid gene sequence (AY187045). Reaction mixtures of $25 \mu \mathrm{l}$ final volume containing $100 \mathrm{ng}$ template, $12.5 \mu \mathrm{l}$ Hot Start Taq Master Mix (Qiagen) and $0.36 \mu \mathrm{M}$ of each primer were incubated at $95^{\circ} \mathrm{C}$ for $15 \mathrm{~min}$ followed by 35 cycles of $95^{\circ} \mathrm{C}$ for $30 \mathrm{~s}, 55^{\circ} \mathrm{C}$ for $30 \mathrm{~s}$ and $72^{\circ} \mathrm{C}$ for $60 \mathrm{~s}$. Final extension was at $72^{\circ} \mathrm{C}$ for $7 \mathrm{~min}$. Products were electrophoresed through $2 \%$ agarose gels in TAE ( $40 \mathrm{mM}$ Tris, $29 \mathrm{mM}$ acetic acid, 1 mM EDTA), and amplicons were visualised by staining with SYBR Safe DNA gel stain (Invitrogen) and a blue-light transilluminator. To further discriminate the magnificent tree frog isolate from other ranaviruses, the intergenic region was amplified using the $16 \mathrm{R}$ and $16 \mathrm{~F}$ primers and sequencing conditions described by Jancovich et al. (2005). Reaction mixtures of $50 \mu \mathrm{l}$ final volume containing $40 \mathrm{ng}$ template, $45 \mu \mathrm{l}$ Platinum PCR
SuperMix (Invitrogen) and $0.2 \mu \mathrm{M}$ of each primer were incubated at $94^{\circ} \mathrm{C}$ for $2 \mathrm{~min}$, followed by 40 cycles of $94^{\circ} \mathrm{C}$ for $30 \mathrm{~s}, 48^{\circ} \mathrm{C}$ for $30 \mathrm{~s}$ and $72^{\circ} \mathrm{C}$ for $60 \mathrm{~s}$. Final extension was at $75^{\circ} \mathrm{C}$ for $5 \mathrm{~min}$. Products were electrophoresed through $1 \%$ agarose gels in TAE, and amplicons were visualised by staining with SYBR Safe DNA gel stain (Invitrogen).

Amplicons of the expected size were cut from the gel using sterile scalpel blades, purified from the agarose using a commercial spin column kit according to the manufacturer's instructions (QIAamp PCR Product Purification Kit, Qiagen) and sequenced by direct product sequencing using the BigDye Terminator v3.1 Cycle Sequencing chemistry and 3130xl Genetic Analyzer (Applied Biosystems) according to the manufacturers' instructions. Each amplicon was sequenced using the forward and reverse primer. Consensus sequences were produced and compared to sequences in the public domain by BlastN searches on the National Center for Biotechnology Information (NCBI) web site (www.ncbi.nlm.nih.gov/ blast/Blast.cgi). Sequences were aligned using ClustalW, and phylogenetic and molecular evolutionary analyses were conducted using MEGA4 (Tamura et al. 2007). Briefly, the evolutionary history was inferred using the neighbour-joining method. The evolutionary distances were computed using the maximum composite likelihood method and are in the units of the number of base substitutions per site. All positions containing gaps and missing data were eliminated from the dataset using the complete deletion option. There were a total of 1108 positions in the final dataset. Comparative nucleotide sequence analysis was undertaken using GeneDoc (www. nrbsc.org/gfx/genedoc).

\section{Real-time PCR detection}

DNA was extracted from $100 \mu \mathrm{l}$ of infected cell culture supernatant using PrepMan Ultra Reagent (Applied BioSystems), according to the manufacturer's instructions. Four real-time assays (Pallister et al. 2007) were undertaken using primers and probes targeting the major capsid protein of ranaviruses, European catfish virus (ECV), EHNV and the intergenic variable region of BIV (Table 1). The test relies on the differential binding pattern of a set of probes to differentiate BIV (BIV probe) from EHNV (EHNV probe), and BIV together with EHNV from the European viruses, European sheatfish virus (ESV) and ECV (EURO probe). The CON probe detects a region conserved in all ranaviruses sequenced so far. 
The $25 \mu$ real-time PCR reaction contained $12.5 \mu \mathrm{l}$ Platinum Quantitative PCR SuperMix-UDG (Invitrogen), $0.625 \mu \mathrm{l}$ of each primer (3.6 $\mu \mathrm{M}$ stock), $0.625 \mu \mathrm{l}$ of probe (1 $\mu \mathrm{M}$ stock), $0.05 \mu$ l of ROX reference dye (Invitrogen), $1 \mu$ template and sterile water. PCR was undertaken in a 7500 Fast Real-time PCR Machine (Applied BioSystems) with cycling conditions of $50^{\circ} \mathrm{C}$ for $2 \mathrm{~min}, 95^{\circ} \mathrm{C}$ for $10 \mathrm{~min}$ and 45 cycles of $95^{\circ} \mathrm{C}$ for $15 \mathrm{~s}$ and $60^{\circ} \mathrm{C}$ for $1 \mathrm{~min}$. EHNV, ECV and BIV were used as positive controls.

\section{Virus isolation}

Virus was isolated from all samples processed for virus culture. BF-2 cultures showed evidence of $\mathrm{CPE}$ $48 \mathrm{~h}$ post inoculation. CPE characteristics included microscopic foci, cell rounding and death, which rapidly progressed to the whole monolayer with complete destruction occurring less than $24 \mathrm{~h}$ later. Cultures that were contaminated with either bacteria or fungi were filtered through a sterile $0.22 \mu \mathrm{m}$ membrane filter and the filtrate inoculated to fresh BF-2 flask(s). The

\section{RESULTS}

\section{Histopathology}

Microscopic lesions were similar to those previously described for the systemic haemorrhagic form of ranavirus disease in frogs. There was multifocal to diffuse necrosis of the splenic parenchyma involving both lymphoid and sinusoidal tissue (Fig. 1a). Multifocal necrosis was also present in the liver and kidney with variable presence of intracytoplasmic basophilic inclusion bodies in hepatocytes (Fig. 1b). In all organs studied we observed vascular necrosis involving predominantly venules.
Table 1. Primer and probe sequences used in the real-time PCR assays. FAM: 6-carboxyfluorescein; MGB: minor groove binder; EHNV: epizootic haematopoietic necrosis virus; ESV: European sheatfish virus; ECV: European catfish virus; BIV: Bohle iridovirus. CON: ranavirus conserved TaqMan assay; EHNV: EHNV-specific TaqMan assay; BIV: BIV-specific TaqMan assay; EURO: ESV and ECV-specific TaqMan assay (from Pallister et al. 2007)

\begin{tabular}{|llc|}
\hline Assay name & Sequence & Specificity \\
\hline CON forward & 5'-CTC ATC GTT CTG GCC ATC AA-3' & EHNV, \\
CON reverse & 5'-TGA ACG GCT CGA TGG GA-3' & ESV, ECV, \\
CON probe & 5'-FAM-CAC AAC ATT ATC CGC ATC-MGB-3' & BIV \\
EURO forward & 5'-CGG TGG ATC CCG TCA AGA-3' & ESV, ECV \\
EURO reverse & 5'-GAA AAC ACC ACA AGG CTC CC-3' & \\
EURO probe & 5'-FAM-TGC CAG CCT GGT GTA-MGB-3' & \\
EHNV forward & 5'-CGA TGG GAT TCC CAA TCT TG-3' & EHNV \\
EHNV reverse & 5'-GTC TTT TCC GTC ATG GGT CCT-3' & \\
EHNV probe & 5'-FAM-AAG AGT ATT TTT CAG CGC AA-MGB-3' \\
BIV forward & 5'-ACA GAG GTG GCC AAA CTG TTG-3' & BIV \\
BIV reverse & 5'-CAC CAA TAG AAA AAG CAA GTG ATG A-3' & \\
BIV probe & 5'-FAM-CAG CCC TAT TTT C-MGB-3' & \\
\hline
\end{tabular}
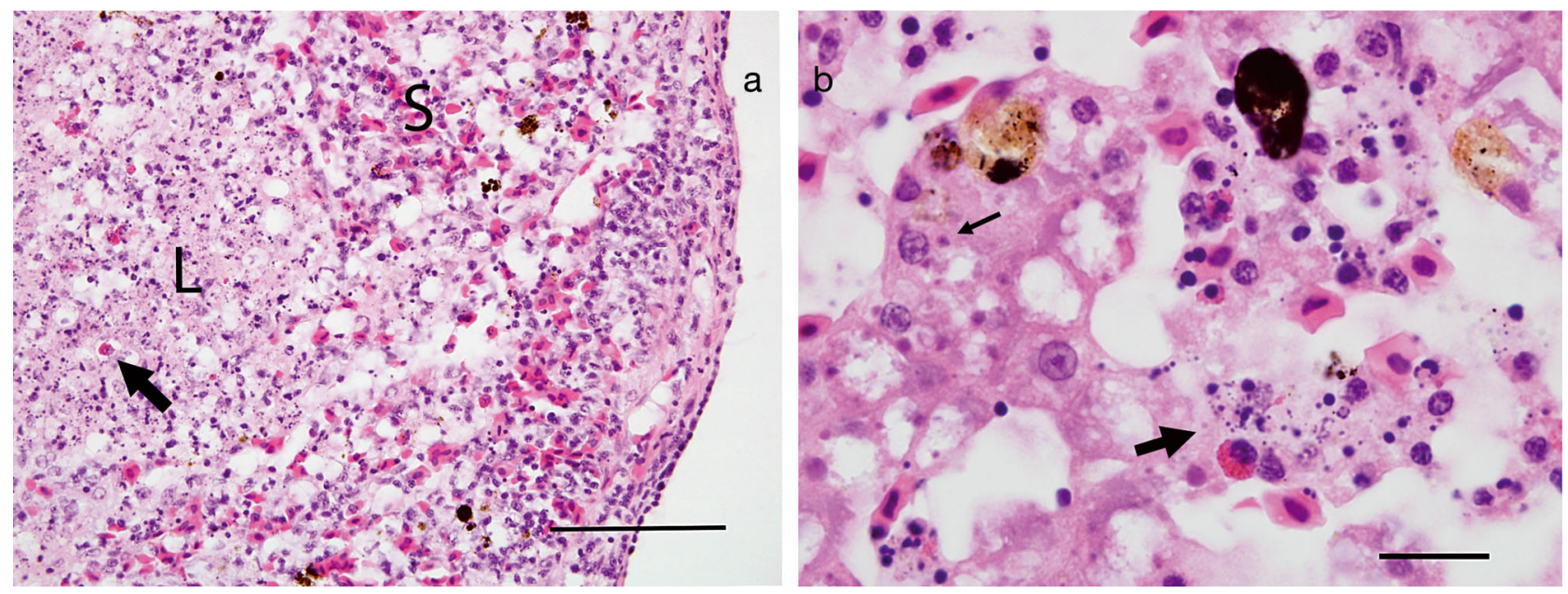

Fig. 1. Litoria splendida. (a) Extensive necrosis of splenic parenchyma, most severe in areas corresponding to lymphoid tissue (L) but also affecting endothelium in sinusoidal tissue (S). There is mild granulocyte infiltration of necrotic tissue (arrow). Stained with haematoxylin and eosin (HE). Scale bar $=100 \mu \mathrm{m}$. (b) Liver, showing extensive hepatocyte necrosis with mild associated granulocyte infiltration (large arrow). Many intact hepatocytes are vacuolated and some contain intracytoplasmic basophilic inclusions (small arrow). Stained with HE. Scale bar $=20 \mu \mathrm{m}$ 
filtered samples exhibited similar CPE characteristics and timing as the samples that were not filtered, demonstrating a filterable infectious agent. Evidence for the presence of an infectious virus was confirmed by subsequent passages in cell cultures where CPE was consistently and repeatedly observed. The virus isolate was provisionally named Mahaffey Road virus (MHRV) and assigned the isolate number DPP7200.

\section{Electron microscopy and laser dissection}

Icosahedral particles of $136 \pm 7 \mathrm{~nm}$ (mean $\pm \mathrm{SD}$ ), ( $n=7$ ) were observed by negative contrast electron microscopy (Fig. 2). Examination of ultrathin sections showed the presence of cytoplasmic viruses which appeared singularly, in paracrystalline arrays and/or aggregates (Fig. 3a). Viruses were present in differ-

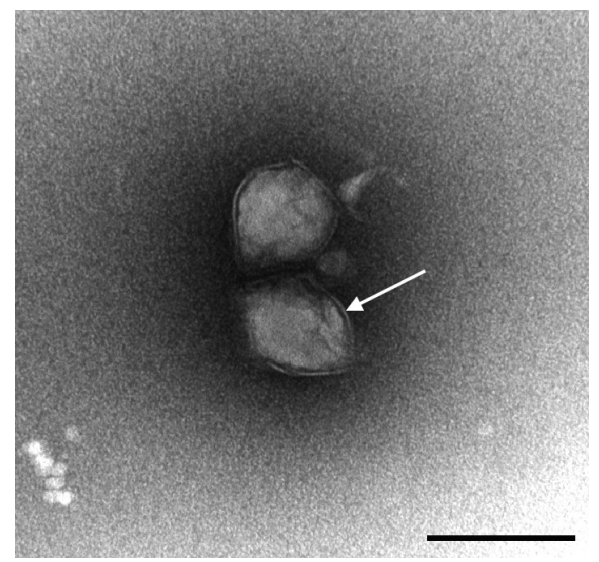

Fig. 2. Transmission electron micrograph of negatively contrasted ranaviruses. The outer capsid is apparent (arrow). Scale bar $=150 \mathrm{~nm}$ ent stages of assembly and were observed budding from the plasma membrane (Fig. 3b).

Cytoplasmic inclusion bodies as identified by electron microscopy and histopathology examination were dissected from the fixed tissue, and sequencing of the PCR products confirmed the presence of ranavirus in the hepatic and splenic lesions.

\section{Restriction enzyme digests, conventional PCR, sequencing and phylogenetic analysis}

Fig. 4 shows restriction enzyme (RE) digestion profiles for MHRV, BIV and EHNV. All 3 RE digest profiles were different for each of the REs. Using the classification of Hyatt et al. (2000), MHRV cannot be assigned to either the BIV or EHNV species.

In less than $24 \mathrm{~h}$, all BF-2 cell cultures were displaying CPE at dilutions in excess of $1 / 20$ and $1 / 200$ but not 1/2000. However, between 24 and 48 h, all cell cultures exhibited CPE in all dilutions. Material was harvested for PCR analysis from the BF-2 cultures after $4 \mathrm{~d}$.

Amplicons of the expected size (321 bp for the 151F/ $152 \mathrm{R}$ primer set; $625 \mathrm{bp}$ for the $153 \mathrm{~F} / 154 \mathrm{R}$ primer set) were produced for the isolate amplified in cell culture after inoculation with MHRV for both primer sets (Fig. 5). Positive reactions were also produced for BIV and both EHNV isolates. No amplicon was produced for template extracted from uninfected cell culture supernatant, and larger amplicons were produced from template extracted from RSIV-infected cell cultures.

Sequencing of the amplicons generated using the $151 \mathrm{~F} / 154 \mathrm{R}$ primer set resulted in a $1161 \mathrm{bp}$ consensus sequence of MHRV (GenBank accession GU292010).
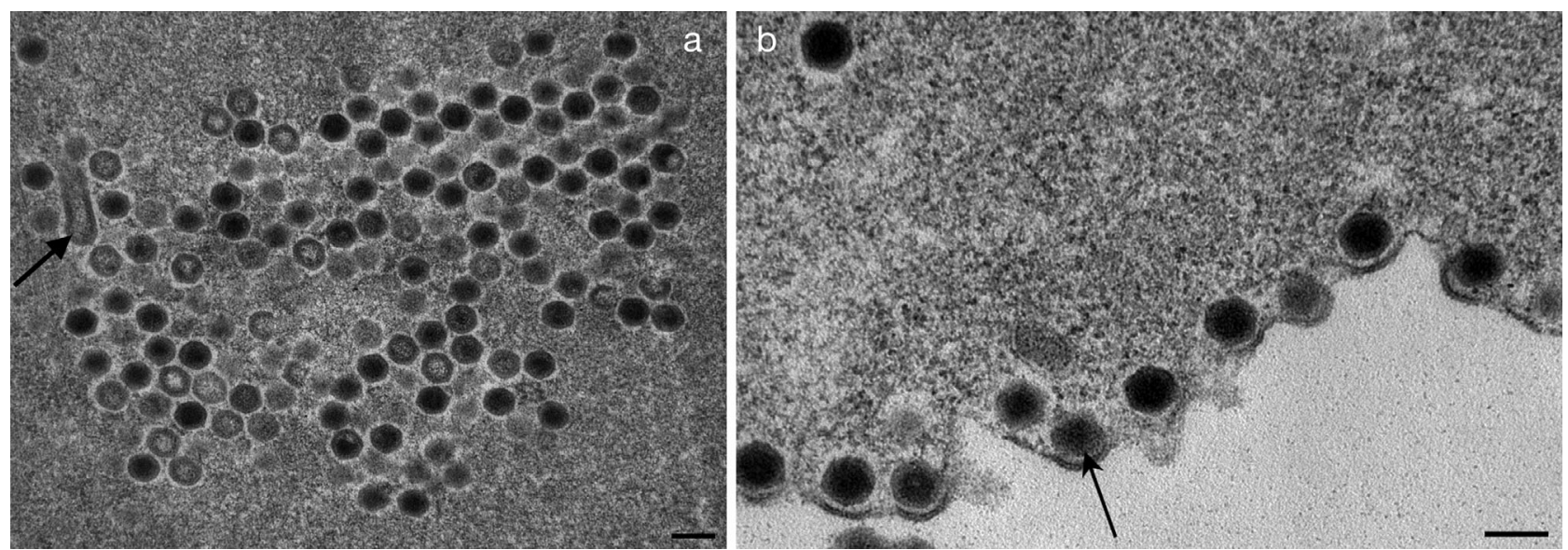

Fig. 3. Transmission electron micrographs of ultrathin sections of cells infected with Mahaffey Road virus (MHRV; DPP7200). (a) Intracytoplasmic aggregation of viruses. Empty and full viruses are apparent; an aberrant form (arrow) is also present. Scale bar $=200 \mathrm{~nm}$. (b) Viruses budding (arrow) from the plasma membrane. Scale bar $=200 \mathrm{~nm}$ 


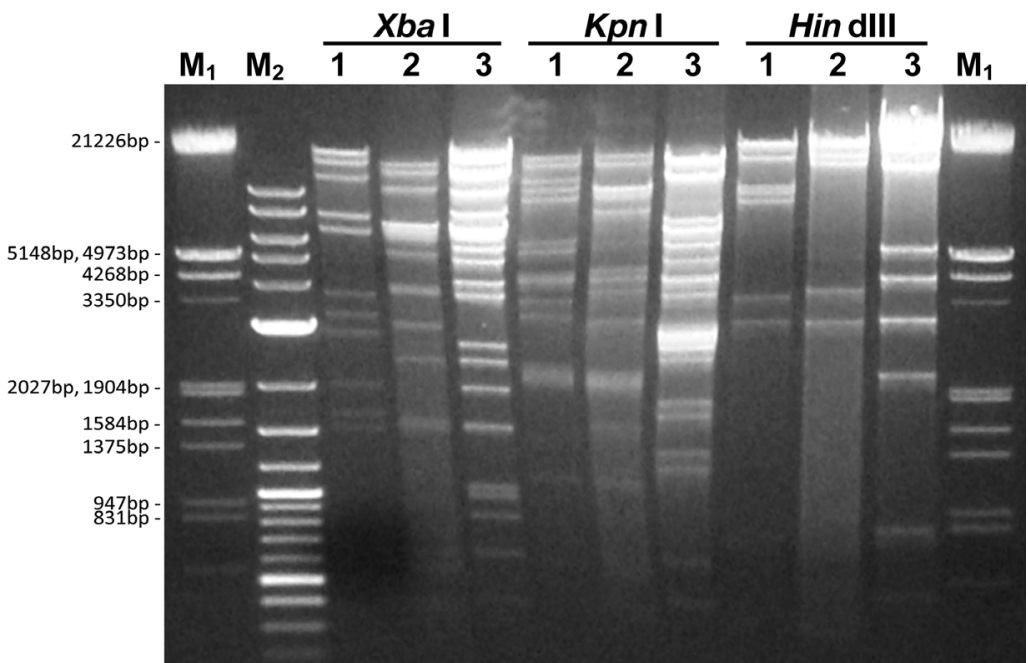

Fig. 4. Restriction enzyme digests of Bohle iridovirus (BIV), Mahaffey Road virus (MHRV) and epizootic haematopoietic necrosis virus (EHNV). $\mathrm{M}_{1}$ : Lambda Hin dIII ECo RV marker; $\mathrm{M}_{2}$ : 2-log DNA ladder; 1 : BIV; 2: MHRV; 3: EHNV
This sequence was most closely related to the sequences from the ranavirus-positive control samples (i.e. BIV and EHNV). Nucleotide similarities were $98.62 \%$ (BIV), 96.9\% (EHNV) and 97.50\% frog virus 3 (FV3). Although high nucleotide similarities were obtained for both amphibian ranaviruses, BIV and FV3, sequence analysis of the intergenic variable region showed that MHRV shared a 48 bp deletion with BIV that was not present in FV3 (Fig. 6). These data indicate that the MHRV isolate should be putatively designated as a member of the genus Ranavirus. This is supported by the higher deduced amino acid homologies between MHRV and the Australian ranavirus isolates than to representative

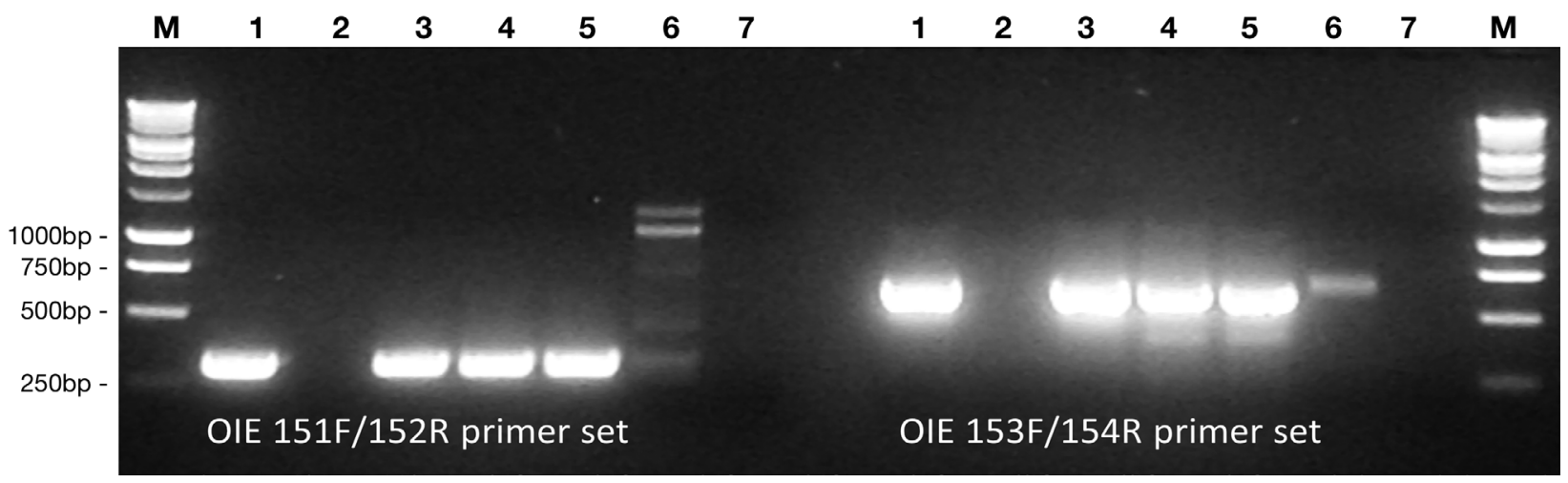

Fig. 5. PCR results using the OIE 151F/152R and 153F/154R primer sets. 1: Mahaffey Road virus (MHRV)-infected cell culture supernatant; 2: Uninfected cell culture supernatant; 3: Bohle iridovirus (BIV)-infected cell culture supernatant; 4: Epizootic haematopoietic necrosis virus, rainbow trout isolate (EHNVrt)-infected cell culture supernatant; 5: EHNV redfin perch isolate (EHNVrp)-infected cell culture supernatant; 6: red seabream iridovirus (RSIV)-infected cell culture supernatant; 7: Notemplate control; M: $1 \mathrm{~kb}$ molecular weight marker

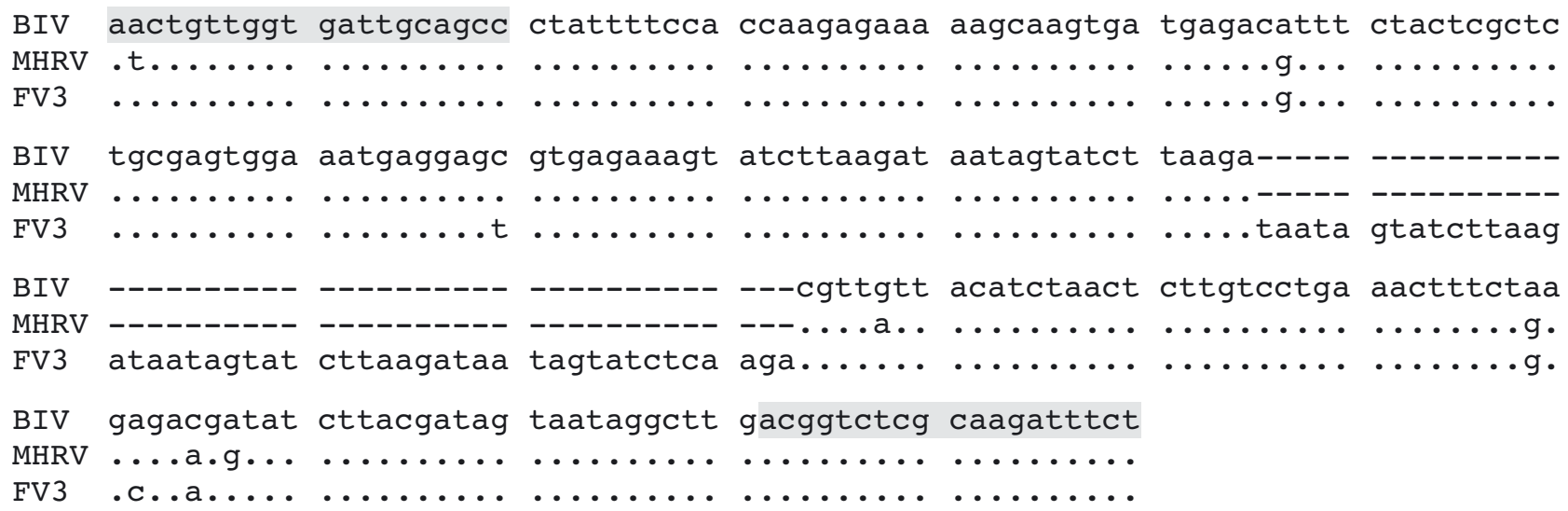

Fig. 6. Sequence alignment of Bohle iridovirus (BIV), Mahaffey Road virus (MHRV) and frog virus 3 (FV3) sequences in the intergenic variable region. Conserved nucleotides are represented by a dot, nucleotide changes are represented by a letter, and nucleotide deletions are shown as a dash. Shaded regions indicate 16F and 16R primer binding sites 
isolates from other genera in the Iridoviridae (Table 2). Similar results were obtained when a BlastN search of the sequence was undertaken on the NCBI website (data not shown). These relationships are supported by the phylogenetic analysis of MHRV where this isolate is grouped with other representatives of the Ranavirus genus, which is distinctly separate from isolates in the other genera of the Iridoviridae (Fig. 7).

\section{Real-time PCR}

A TaqMan real time PCR assay has been developed that is designed to quickly differentiate between different groups of ranaviruses that infect amphibians and fish in different parts of the world (Pallister et al. 2007). DNA extracted from the MHRV isolate was used to determine whether the results

Table 2. Percent nucleotide similarities (upper right) and deduced amino acid homologies (lower left) between Mahaffey Road virus (MHRV), generated using the 151F/154R primer set, and sequences from GenBank (accession numbers in parentheses). BIV: Bohle iridovirus; EHNV: epizootic haematopoietic necrosis virus; FV3: frog virus 3; RSIV: red seabream iridovirus; WIV:

Wiseana iridescent virus; LCDV: lymphocystis disease virus

\begin{tabular}{|lcccccrc|}
\hline Isolate & $\begin{array}{c}\text { MHRV } \\
\text { (GU292010) }\end{array}$ & $\begin{array}{c}\text { BIV } \\
\text { (AY187046) }\end{array}$ & $\begin{array}{c}\text { EHNV } \\
\text { (AY187045) }\end{array}$ & $\begin{array}{c}\text { FV3 } \\
\text { (FVU36913) }\end{array}$ & $\begin{array}{c}\text { RSIV } \\
\text { (AB263097) }\end{array}$ & $\begin{array}{c}\text { WIV } \\
\text { (AF025774) }\end{array}$ & $\begin{array}{c}\text { LCDV } \\
\text { (AY823414) }\end{array}$ \\
\hline MHRV (GU292010) & - & 98.62 & 96.90 & 97.50 & 55.64 & 46.34 & 49.01 \\
BIV (AY187046) & 97.32 & - & 97.85 & 98.71 & 56.25 & 46.25 & 48.84 \\
EHNV (AY187045) & 93.85 & 96.00 & - & 97.67 & 56.59 & 45.65 & 48.67 \\
FV3 (FVU36913) & 95.72 & 97.87 & 95.48 & - & 56.42 & 46.25 \\
RSIV (AB263097) & 29.14 & 30.13 & 30.32 & 30.05 & - & 47.39 & 48.49 \\
WIV (AF025774) & 20.32 & 20.00 & 19.68 & 19.95 & 26.07 & - & 49.05 \\
LCDV (AY823414) & 22.99 & 22.67 & 22.34 & 22.34 & 24.36 & 32.10 & - \\
\hline
\end{tabular}

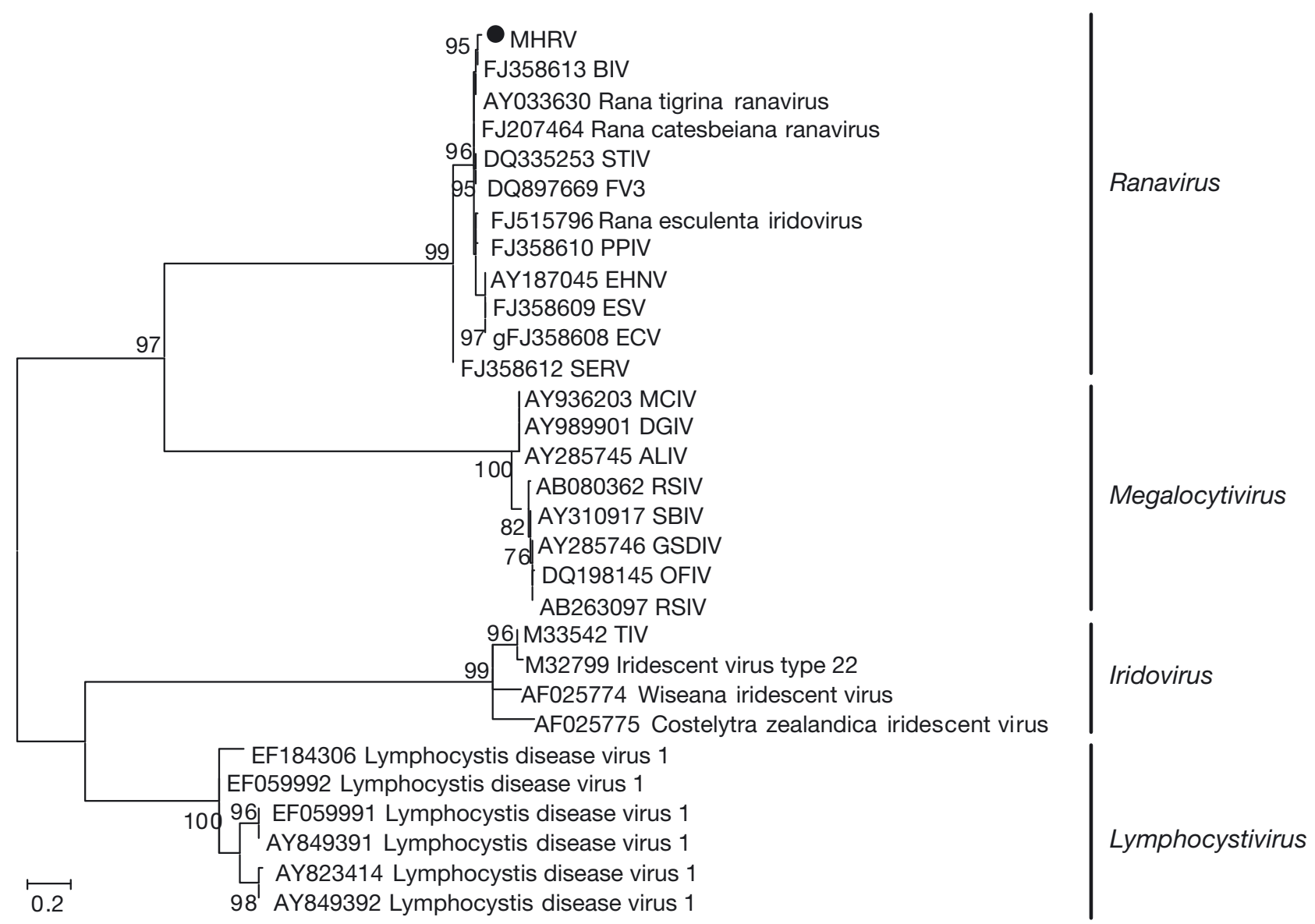

Fig. 7. Phylogenetic relationship of Mahaffey Road virus (MHRV; GU292010, @) with representative Ranavirus, Megalocytivirus, Iridovirus and Lymphocystivirus isolates. Scale bar indicates the number of base substitutions per site 
obtained using this assay were consistent with the results of other tests reported here (Table 3).

The CON probe bound to DNA from all 4 viruses tested. The pattern of binding of the other 3 probes to DNA from the MHRV isolate was most similar to the pattern generated with BIV DNA, where the BIV probe only bound to DNA from BIV and the MHRV isolate.

\section{DISCUSSION}

A survey of the native frog population in the Darwin rural area has not been conducted, and sampling of the native frog population for virus isolation is yet to be done on the property. There has been no observed increase in mortalities or decrease in population of the native frog population in the area. MHRV could be endemic to the frogs inhabiting the property and environs, coming into contact indirectly with the affected animals through excreta passing into the pens from the top of the enclosures. The frogs (Litoria caerulea) that had more opportunity to interact with the frogs inhabiting the property had smaller numbers affected and a lower mortality than the 'exotic' frogs (L. splendida) that had been collected at Bullo River, approximately $400 \mathrm{~km}$ south of Darwin.

Histological examination of the organs from both Litoria splendida and L. caerulea displayed pathological changes that were consistent with viral infections seen in other amphibians (Cunningham et al. 1996). These changes included multifocal necrosis of hepatic, renal and splenic tissue from which iridoviruses have been isolated or visualised and vascular necrosis involving all organs examined. Sequencing of PCR products from some of the excised lesions (laser dissection) confirmed that ranaviruses were present within the lesions and that these products were identical to that of the MHRV isolate.

Table 3. Cycle threshold (Ct) values obtained with the CON, EHNV, BIV and EURO TaqMan probes (see Table 1) using DNA extracted from cells infected with European sheatfish virus (ESV), epizootic haematopoietic necrosis virus (EHNV), Bohle iridovirus (BIV) or the Mahaffey Road virus (MHRV) isolates

\begin{tabular}{|c|c|c|c|c|}
\hline \multirow{2}{*}{$\begin{array}{l}\text { Source } \\
\text { DNA sample }\end{array}$} & \multirow[b]{2}{*}{$\mathrm{CON}$} & \multicolumn{2}{|c|}{ Probe and $\mathrm{Ct}$ value - } & \multirow[b]{2}{*}{ BIV } \\
\hline & & EURO & EHNV & \\
\hline ESV & 21.46 & 21.06 & Neg & Neg \\
\hline EHNV & 19.49 & 22.02 & 20.94 & Neg \\
\hline BIV & 25.97 & 28.67 & 30.03 & 26.80 \\
\hline MHRV & 21.12 & 25.13 & 25.72 & 23.99 \\
\hline
\end{tabular}

Restriction endonuclease profiles obtained using XbaI, KpnI and HindIII of the virus isolated in cell culture indicated that none of the isolates was sufficiently similar to EHNV or BIV to be included in a single group as defined by Hyatt et al. (2000). The latter authors also found that isolates clustering in a single virus group appeared to originate in a single geographic location. The restriction endonuclease profiles of the 3 Australian viruses are very diverse, which is not surprising if the geographical distance separating the origins of these viruses is considered: BIV from Townsville in northern Queensland, EHNV from Lake Nhillacootie in Victoria (approximately 2500 and $3800 \mathrm{~km}$ from Darwin, respectively) and MHRV from the Darwin rural area in the Northern Territory.

We analysed the MHRV isolate using a TaqMan real-time PCR assay that had been developed to differentiate specified ranaviruses. The assay indicated that the MHRV isolate was a ranavirus and that it was more similar to BIV than it was to either EHNV or the European ranaviruses, ESV/ECV. The identity of the isolate was confirmed using international standard PCR assays for the detection of EHNV (OIE 2006). Sequencing of the $1161 \mathrm{bp}$ amplicon confirmed the close relationship of MHRV to BIV and to a lesser extent, to EHNV and FV3 (Table 2, Fig. 5). To explore this similarity further, we sequenced the intergenic variable region targeted by the BIV probe. The intergenic variable region was identified when salamander ranavirus isolates were compared and found to vary in this region by the number of copies of a $16 \mathrm{bp}$ repeat sequence (Jancovich et al. 2005). Our previous results (unpublished data) showed that this region also varied between BIV, EHNV and ESV/ECV. There was a deletion of approximately 500 bp in BIV compared with EHNV and ESV/ECV, while overall identity between EHNV and ESV/ECV in this region was only $48 \%$. Sequence identity between FV3 and BIV was $83 \%$ (Pallister et al. 2007). Sequence data from the intergenic variable region of the MHRV isolate showed a $98.9 \%$ identity with the same region from BIV. Collectively, these results indicate that BIV and the MHRV isolate are very closely related, although both isolates are distinguishable from each other by restriction enzyme digests; future full genome sequencing is required to confirm the similarity. The sequence data from this study confirmed that the intergenic region of the MHRV genome was more similar to BIV than to FV3. Whilst FV3 carries 4 copies of a repeat sequence in this region of the genome, BIV and the MHRV carry only 1 repeat. Across the $212 \mathrm{bp}$ of common sequence (MHRV and BIV) there are only 4 bp changes 
or $1.9 \%$ of the genome region sequenced. Together, these data suggest that the MHRV DNA is very similar to that of BIV in the regions targeted by the realtime PCR assay.

The ranavirus isolated from the captive native frogs in this study is distinct from the BIV isolated from metamorphs in Queensland (Speare \& Smith 1992) on the eastern seaboard of Australia. Given the potential devastating effect of infection in the wild population of Litoria splendida (a species with a localised geographic distribution), and the possibility that ranaviruses can jump species (Jancovich et al. 2010), further research is required to investigate the natural occurrence and distribution of MHRV in this region of Australia. The potential of MHRV posing a risk to the local farmed finfish industry can also not be dismissed, as work by Jancovich et al. (2010) concluded that ranaviruses can undergo 'host shifts' with subsequent speciation in new host species. When the BIV was used to experimentally inoculate barramundi, $100 \%$ mortality was observed (Moody \& Owens 1994). The proximity of potentially infected native amphibians to terrestrial fish farms is a risk that should not be discounted, and consideration should be given to conducting a survey of anurans to determine the distribution of the MHRV.

Acknowledgements. We are grateful to N. Williams for the preparation of material for molecular work and to M. Harmsen and $\mathrm{S}$. Walsh for their assistance in virus isolation.

\section{LITERATURE CITED}

Chinchar VG, Hyatt A, Miyazaki T, Williams T (2009) Family Iridoviridae: poor viral relations no longer. Curr Top Microbiol Immunol 328:123-170

Cullen BR, Owens L (2002) Experimental challenge and clinical cases of Bohle iridovirus (BIV) in native Australian anurans. Dis Aquat Org 49:83-92

> Cunningham AA, Langton TES, Bennettt PMB, Lewin JF, Drury SEN, Gough RE, Macgregor SK (1996) Pathological and microbiological findings from incidents of unusual mortality of the common frog (Rana temporaria). Philos Trans R Soc Lond B Biol Sci 351: 1539-1557

Densmore CL, Green DE (2007) Diseases of amphibians. ILAR J 48:235-254

Fauquet CM, Mayo MA, Maniloff J, Desselberger U, Ball LA

Editorial responsibility: Cynthia Carey,

Boulder, Colorado, USA (eds) (2005) Virus taxonomy, 8th edn. Elsevier Academic Press, London

Fox SF, Greer AL, Torres-Cervantes R, Collins JP (2006) First case of ranavirus-associated morbidity and mortality in natural populations of the South American frog Atelognathus patagonicus. Dis Aquat Org 72:87-92

> Hyatt AD, Gould AR, Zupanovic Z, Cunningham AA and others (2000) Comparative studies of piscine and amphibian iridoviruses. Arch Virol 145:301-331

> Hyatt AD, Williamson M, Coupar BE, Middleton D and others (2002) First identification of a ranavirus from green pythons (Chondropython viridis). J Wildl Dis 38:239-252

Jancovich JK, Davidson EW, Parameswaran N, Mao J and others (2005) Evidence for emergence of an amphibian iridoviral disease because of human-enhanced spread. Mol Ecol 14:213-224

Jancovich J, Bremont M, Touchman JW, Jacobs L (2010) Evidence for multiple host species shifts among the ranaviruses (Family Iridoviridae). J Virol 84:2636-2647

> Langdon JS, Humphrey JD, Williams LM, Hyatt AD, Westbury HA (1986) First virus isolation from Australian fish: an iridovirus-like pathogen from redfin perch, Perca fluviatilis L. J Fish Dis 9:263-268

Langdon JS, Humphrey JD, Williams LM (1988) Outbreaks of an EHNV-like iridovirus in cultured rainbow trout, Salmo gairdneri Richardson, in Australia. J Fish Dis 11:93-96

Marsh IB, Whittington RJ, O'Rourke B, Hyatt AD, Chisholm O (2002) Rapid differentiation of Australian, European and American ranaviruses based on variation in major capsid protein gene sequence. Mol Cell Probes 16: 137-151

> Moody NJG, Owens L (1994) Experimental demonstration of the pathogenicity of a frog virus, Bohle iridovirus, for a fish species, barramundi Lates calcarifer. Dis Aquat Org 18:95-102

OIE (World Organisation for Animal Health) (2006) Manual of diagnostic tests for aquatic animals. OIE, Paris

> Pallister J, Gould A, Harrison D, Hyatt A, Jancovich J, Heine H (2007) Development of real-time PCR assays for the detection and differentiation of Australian and European ranaviruses. J Fish Dis 30:427-438

Sato M, Maeda N, Yoshida H, Urade M and others (1977) Plaque formation of herpes virus hominis type 2 and rubella virus in variants isolated from the colonies of BHK21/WI-2 cells formed in soft agar. Arch Virol 53: 269-273

Speare R, Smith JR (1992) An iridovirus-like agent isolated from the ornate burrowing frog Limnodynastes ornatus in northern Australia. Dis Aquat Org 14:51-57

> Tamura K, Dudley J, Nei M, Kumar S (2007) MEGA4: Molecular evolutionary genetics analysis (MEGA) software version 4.0. Mol Biol Evol 24:1596-1599

> Zupanovic Z, Musso C, Lopez G, Louriero CL, Hyatt AD, Hengstberger S, Robinson AJ (1998) Isolation and characterization of iridoviruses from the giant toad Bufo marinus in Venezuela. Dis Aquat Org 33:1-9

Submitted: December 29, 2009; Accepted: March 26, 2012 Proofs received from author(s): June 25, 2012 